\title{
Potential of Greenhouse Gas Production by Guinea Grass Subjected to Weed Competition
}

\author{
Sidnei Roberto de Marchi ${ }^{1}$, Amanda Cristina de Sousa ${ }^{1}$, Ricardo Fagundes Marques ${ }^{2}$, \\ Guilherme Henrique Rodrigues Pinheiro ${ }^{2}$, Rodrigo Marques de Souza ${ }^{1} \&$ Dagoberto Martins ${ }^{3}$ \\ ${ }^{1}$ Universidade Federal do Mato Grosso, Campus Universitário do Araguaia, Brazil \\ ${ }^{2}$ Universidade Federal de Goiás, Regional Jataí, Brazil \\ ${ }^{3}$ Faculdade de Ciências Agrárias e Veterinárias, Campus de Jaboticabal, Brazil \\ Correspondence: Sidnei R. de Marchi, Universidade Federal do Mato Grosso, Campus Universitário do Araguaia, \\ Av. Valdon Varjão, 1693, Barra do Garças, MT, Zip 78600-000, Brazil. E-mail: sidneimarchi.ufmt@gmail.com
}

Received: March 10, 2019

doi:10.5539/jas.v11n8p257

\author{
Accepted: April 25, 2019 Online Published: June 15, 2019 \\ URL: https://doi.org/10.5539/jas.v11n8p257
}

\begin{abstract}
The world population growth and the increasing purchasing power have raised the demand for animal proteins, especially meat and milk. This has made it essential to intensify livestock production by making it productive, efficient and at the same time sustainable, which today is a great challenge for cattle ranchers. The objective of this study is to evaluate the effects of coexistence with weeds on productivity, nutritional quality and potential of greenhouse gas (GHG) emission by Guinea grass (Panicum maximum cv. Mombasa) in pasture renewal conditions. The experiment was set up in randomized blocks, four replications, with treatments consisting of eight periods of coexistence: $0,15,30,45,60,75,90$ and 120 days after seedlings emergence. Phyto-sociological evaluations were performed in the weed community at the end of each coexistence period. The Guinea grass was evaluated as for morphological, chemical and bromatological parameters and as for the potential of total gas, methane and carbon dioxide emission. The results show that productivity, nutritional quality and energy value of Guinea grass decreases proportionally to the increase in the period of coexistence with weeds. The non-coexistence with weeds provides a better in vitro digestibility of organic matter and, consequently, decreases the GHG emission potential by the dry matter of Guinea grass.
\end{abstract}

Keywords: Panicum maximum, morphogenesis, energetic value, digestibility, methane, carbon dioxide.

\section{Introduction}

The model of cattle production based on extensive areas has been historically practice in most tropical countries. This extensive model is based on extractive activities in which the needs of soil-plant system are not considered. (Macedo, 2009; Santos et al., 2011).

The role of forage plants in extensive model is of primary importance with regard to animal production. It has a direct impact on zootechnical indexes and socioeconomic aspects of most tropical countries. Thus, pastures are one of the main factors responsible for the sustainability and viability of several animal production systems, especially ruminants (Gléria et al., 2017).

Guinea grass (Panicum maximum Jacq. cv 'Mombaça') is a forage plant from Africa recommended for soil areas with a high fertility, offering an excellent option for the diversification of pastures (Euclides et al., 2008). This grass stands out because of its high dry matter production potential, the quality and palatability of the forage produced, good pasture persistence and resistance to the pests such as Deois sp., Zulia entreriana and Mahanarva fimbriolata (Jank et al., 2013). However, the production capacity of Guinea grass is intrinsically related to the environmental conditions prevailing in an area and to the management practices adopted. Factors such as temperature, water and nutrients may influence the photosynthesis potential of the canopy due to changes in leaf area and the photosynthetic capacity of the plant (Marcelino et al., 2006).

In addition to the abiotic factors mentioned, some biotic factors may also change the productivity of forage plants. Among the several biotic factors, the presence of weeds determines the action (or causes changes in the intensity of action) of several ecological factors, some favorable and others unfavorable to the interests of the cattle rancher. Possibly, the main problem caused by weeds in pastures is a direct competition for space, light, water and nutrients, 
causing a reduction of the physiological reserves of forages. Such competition, associated with the grazing of animals, causes a series of damages to pastures, which favor the survival of invading plants (Marchi et al., 2017).

Upon competing for growth factors, weeds may also reduce the grasses' capacity to support pastures, increase pasture formation and recovery time, cause injury and/or intoxication, and compromise the aesthetics of the property (Carvalho et al., 2016; Bellé et al., 2018; Marchi et al., 2019). Thus, the extractive aspects of the system of exploitation associated with the consequences of the presence of weeds compel animals to eat foods with a low nutritional value, which provides lower feed efficiency, lower animal performance and, consequently, higher methane emission $\left(\mathrm{CH}_{4}\right)$ per kilogram of meat produced (De Zen et al., 2008).

It is of extreme importance to note that the emission of $\mathrm{CH}_{4}$ is not only associated with environmental problems related to greenhouse effects, but also represents energy losses of the food consumed by animals. This energy should be used to meet the desired production level (Sejian et al., 2011). For this reason, feed strategies for ruminants should be developed to minimize the energy losses that occur during the methanogenesis process and, therefore, provide an increased productivity of the sector while reducing greenhouse gas emissions (Kumar et al., 2009) and increasing the economic viability of the system.

The objective of this work was to study the interaction of weeds with the productive components, nutritional quality, energy potential and greenhouse gas $(\mathrm{GHG})$ production potential of Guinea grass in grazing renewal conditions.

\section{Material and Methods}

\subsection{Description of the Area}

The experimental phase of this research was conducted in a degraded pasture area located at the geographic coordinates $15^{\circ} 52^{\prime} 29^{\prime \prime} \mathrm{S}$ and 52 $2^{\circ} 18^{\prime} 37^{\prime \prime} \mathrm{W}$ from December 2013 to May 2014. The climate of the region, according to the Köppen classification, is Aw. It is characterized by average temperatures above $27{ }^{\circ} \mathrm{C}$ in the hottest months (November to February), average temperatures over $18{ }^{\circ} \mathrm{C}$ in the coldest months (June to August), and average annual rainfall between 1,000 and 1,500 $\mathrm{mm}$, distributed in two well-defined periods: a season of intense rains from October to March and a period of drought between April and September.

The soil of the area is classified as a Red-Yellow Latosol, and had the following chemical and physical characteristics: $\mathrm{pH}$ in $\mathrm{CaCl}_{2}$ of 4.3, $22.0 \mathrm{~g} \mathrm{dm}^{-3}$ of organic matter, $3.8 \mathrm{mg} \mathrm{dm}^{-3}$ of P resin, $\mathrm{V}$ of $23.5 \%$, contents of $\mathrm{K}$, $\mathrm{Ca}, \mathrm{Mg}$ and $\mathrm{H}+\mathrm{AL}$ of $0.15,0.66,0.42$ and $4.0 \mathrm{cmolc} \mathrm{dm}^{-3}$, respectively, $692 \mathrm{~g} \mathrm{~kg}^{-1}$ of sand, $97 \mathrm{~g} \mathrm{~kg}^{-1}$ of silt and 211 $\mathrm{g} \mathrm{kg}^{-1}$ of clay, which characterizes it as having a sandy loam texture.

The preparation of the area was carried out initially by eliminating the existing vegetation by a post-emergence application of the herbicide glyphosate at the dose of $3.0 \mathrm{~L} \mathrm{ha}^{-1}$.

After, soil fertility was corrected according to the recommendations of Vilela et al. (2004), by which the equivalent of 2,000 kg ha ${ }^{-1}$ of limestone was applied to raise the base saturation to $50 \%$. Later, a procedure of incorporation of limestone and elimination of vegetal remains was performed. Sowing fertilization consisted of $250 \mathrm{~kg} \mathrm{ha}^{-1}$ of the formulation 5-25-15 $\left(\mathrm{N}^{-} \mathrm{P}_{2} \mathrm{O}_{5}-\mathrm{K}_{2} \mathrm{O}\right)$, manually distributed over the soil surface.

The sowing of Guinea grass was carried out at the beginning of the rainy season with a uniform grain distribution machine applying the equivalent of $8.0 \mathrm{~kg} \mathrm{ha}^{-1}$ of seeds. Soon afterwards, the seeds were manually incorporated to the soil at the average depth of $2.0 \mathrm{~cm}$ using a comb.

The experiment was arranged according to a randomized complete blocks design with four replications. The treatments consisted of eight periods of coexistence of the weed community with the forage grass $(0,15,30,45,60$, 75,90 and 120 days after the emergence of plants-DAE). The treatment equivalent to 0 (zero) day was considered as the absolute control, in which there was a total absence of coexistence between weeds and forages during the entire period of conduction of the experiment.

\subsection{Weed Community Evaluation}

The characterization of the weed population was performed by phytosociological survey at the end of each coexistence period. The evaluations were carried out in the useful area of each experimental plot using a $0.50 \times$ $0.50 \mathrm{~m}$ plastic frame randomly placed inside the plots. The species forming the weed community inside the frame were identified, numerically quantified and taken to the laboratory. There, they were washed, packed in paper bags and dried in a forced-air circulation oven at $65^{\circ} \mathrm{C}$ for 72 hours until constant weight. After this procedure, the dry biomass of shoots of the collected species was determined using a precision scale of $0.01 \mathrm{~g}$. The relative importance of the species (RIs), which simultaneously expresses the density, dominance and frequency of the 
individuals present in the weed community (Monquero et al., 2014), was determined by the number and dry biomass of plants.

At the end of each coexistence period, the weed community was removed from the plot by application of $1.5 \mathrm{~L} \mathrm{ha}^{-1}$ of herbicide formulated on the basis of $40 \mathrm{~g} \mathrm{~L}^{-1}$ of acid equivalent of aminopyralid $+320 \mathrm{~g} \mathrm{~L}^{-1}$ of acid equivalent of 2,4-D applied at plant post-emergence. Applications of the herbicide were carried out whenever necessary with a $\mathrm{CO}_{2}$ pressurized spray containing a four-tip spreader bar XR 11002 calibrated to dispense the volume of syrup equivalent to $200 \mathrm{~L} \mathrm{ha}^{-1}$.

\subsection{Forage Morphostructural Characteristics}

The morphometry and the structure of Guinea grass were evaluated at the end of the experiment period, that is, at 120 days after emergence (DAE) of seedlings. At this point, tiller height $(\mathrm{cm})$, tiller diameter $(\mathrm{mm})$, height of the first green leaf $(\mathrm{cm})$, number of green leaves and number of dry leaves were determined in ten tillers randomly collected within each plot. The tillers were then fractionated into leaf and stem, and the dry biomass of the respective fractions was obtained according to the aforementioned methodology. It was possible to determine the relation between green leaf dry biomass/green stem dry biomass (leaf/stem) using the dry biomass data. The ratio tiller height/height of the first green leaf (HT/HFGL) was determined using height data.

The productivity of Guinea grass was also evaluated at 120 DAE. We obtained the average height $(\mathrm{m})$ of the forage canopy. Soon afterwards, we collected samples by cutting the plants at $10 \mathrm{~cm}$ of height from the soil within the area delimited by the of $0.50 \times 0.50 \mathrm{~m}$ plastic frame. The samples were randomly chosen within the experimental unit. Then, they were taken to the laboratory and fractionated into green leaves, green stems and dead matter. The dry biomasses of green leaf $(\mathrm{g})$, green stem $(\mathrm{g})$, dead matter $(\mathrm{g})$ and total matter $(\mathrm{g})$ were obtained according to the methodology previously described. The inflorescences eventually existing were considered as green stems.

With the dry biomass data it was possible to estimate the yield $\left(\mathrm{g} \mathrm{m}^{-2}\right)$. The volumetric density $\left(\mathrm{g} \mathrm{m}^{-3}\right)$ of respective fractions was obtained dividing the yield by the height of the forage canopy.

\subsection{Forage Nutritional Quality}

Other samples of forage grass were collected at $120 \mathrm{DAE}$, and dried in the laboratory as mentioned previously, but without any fractionation. The dried samples were then ground in a Willey mill until they reached a particle size of $1.0 \mathrm{~mm}$.

Half the milled samples were sent to the laboratory to determine crude protein (CP), neutral detergent fiber (NDF), acid detergent fiber (ADF) and indigestible neutral detergent fiber (iNDF) as proposed by Silva and Queiroz (2002). The analyses of acid detergent insoluble nitrogen (ADIN) and acid detergent fiber-bound nitrogen (N-ADF) were performed according to the methodology proposed by Licitra et al. (1996). The analyses of in vitro digestibility of organic matter (IVDOM), total digestible nutrient (TDN), digestible energy (DE) and metabolizable energy (ME) were performed as proposed by Seker (2002).

The levels of CP, NDF, FDA, ADF, iNDF, ADIN, N-ADF and IVDOM are expressed as dry matter percentage $(\% \mathrm{DM})$, and DE and ME values are expressed as mkal kg ${ }^{-1}$ of DM.

\subsection{Potential in vitro Gas Production}

The other half of the ground samples was used to evaluate Guinea grass as for the potential of total gas production, $\mathrm{CH}_{4}$ and carbon dioxide $\left(\mathrm{CO}_{2}\right)$, following a methodology adapted and proposed by Paschoaloto et al. (2016), where the gas produced over a 24 -hour period is expressed as $\mathrm{mL} \mathrm{g}^{-1}$ of $\mathrm{DM}$. The gas concentration was analyzed using a Trace GC UltraTM gas chromatograph, Thermo Scientific.

\subsection{Statistical Analysis}

The results of morphology, productivity, nutritional quality and gas production potential variables were subjected to analysis of variance by F test using the AgroEstat statistical software (Barbosa \& Maldonado Jr., 2015). The effects of the treatments were compared by Scott Knott test $(P \leq 0.05)$ and are expressed as mean values $( \pm$ mean standard error). The results of the leaf/culm and HT/HFGL ratios and the IVDOM, TDN, ME and DE values were submitted to regression analysis, and the degrees of freedom of the evaluated factor were unfolded into linear, quadratic and cubic effects by the software Origin 8.5.1 SR1. For the choice of the regression model, the highest value of the coefficient of determination $\left(R^{2}\right)$ was taken into account at $p \leq 0.05$, according to the $F$ test, respecting the biological response. 


\section{Results}

\subsection{Climatic Conditions and Phytosociological Analysis}

The average daily temperatures were between 25 and $30{ }^{\circ} \mathrm{C}$, and the overall mean obtained throughout the experimental period was $26{ }^{\circ} \mathrm{C}$. The mean of the incident global radiation was $16.97 \mathrm{MJ} \mathrm{m}^{-2} \mathrm{day}^{-1}$, and the total rainfall in the period was $1,242 \mathrm{~mm}$, representing averages greater than $100 \mathrm{~mm}$ of rainfall per month.

The dependence of climatic factors, such as temperature and humidity, are important characteristics for a good development of plants with a $\mathrm{C} 4$ metabolism of assimilation of carbon dioxide. Because it is a tropical grass, the main climatic conditions for the production of the Guinea grass are temperatures above $15{ }^{\circ} \mathrm{C}$, annual rainfall between 760 and 1,300 mm, and incident global radiation of at least $12.0 \mathrm{MJ} \mathrm{cm}^{-2}$ day $^{-1}$ (Magalhães et al., 2011; Antoniel et al., 2016). Thus, there were no restrictions of environmental factors during the period of this study that could cause problems for the vegetative development of Guinea grass.

The evaluation of the weed community conducted throughout the experimental period revealed the occurrence of different species distributed into eight families. The Malvaceae family was the most representative, with three species, followed by the Rubiaceae family, with two species (Table 1).

Table 1. Scientific name, family and international codes of weeds within the experimental area

\begin{tabular}{lll}
\hline Scientific Name & Family & International Code \\
\hline Amaranthus retroflexus L. & Amaranthaceae & AMARE \\
Diodia teres Walter & Rubiaceae & DIQTE \\
Spermacoce latifólia Aubl. & Rubiaceae & BOILF \\
Waltheria americana L. & Malvaceae & WALAM \\
Sida rhombifolia L. & Malvaceae & SIDRH \\
Sidastrum micranthum (A. St. - Hil.) Fryxell & Malvaceae & SIDMI \\
Ipomoea grandifolia (Dammer) O` Donell & Convolvulaceae & IAOGR \\
Senna obtusifolia (L.) H.S. Irvin \&Barneby & Leguminoseae & CASOB \\
Hyptis suaveolens (L.) Kuntze & Lamiaceae & HYPSU \\
Triumfetta bartramia L. & Tiliaceae & TIUBA \\
Cyperus difformis L. & Cyperaceae & CYPDI \\
\hline
\end{tabular}

Note. The phytosociological study indicated that Senna obtusifolia (CASOB) presented the highest RIs values $(27-40 \%)$ in evaluations performed up to 90 DAE. The species Hyptis suaveolens (HYPSU) presented increasing values of RIs. From 90 DAE, it exceeded CASOB in terms of importance (Figure 1).

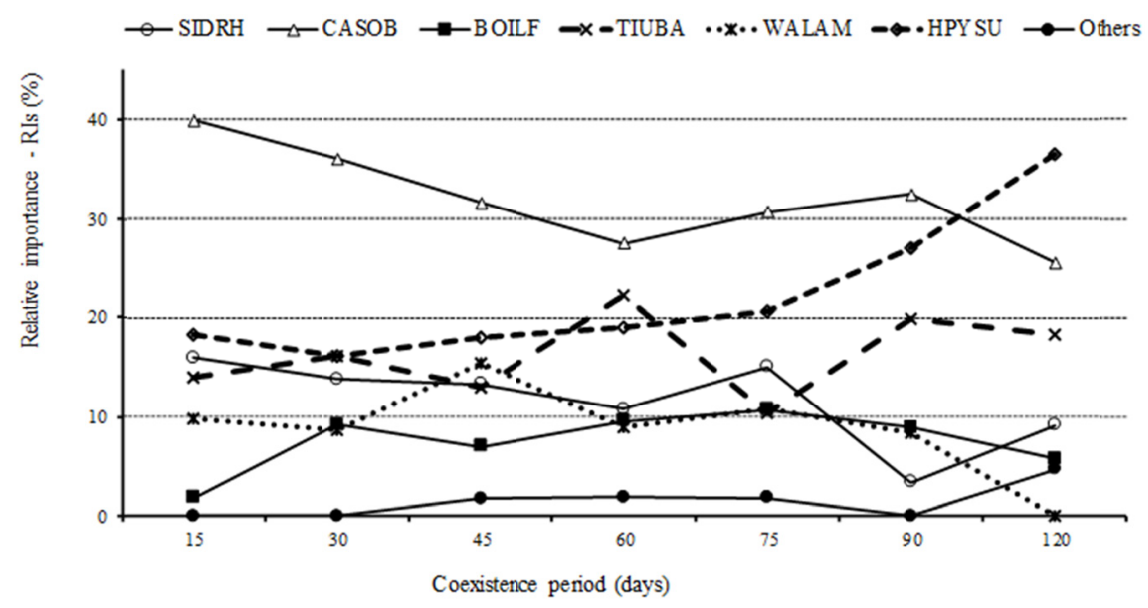

Figure 1. Relative importance (\%) of the weed community obtained for the respective periods of coexistence. SIDRH-Sida rhombifolia. CASOB-Senna obtusifolia. BOILF-Spermacoce latifolia. TIUBA-Triunfetta bartramia. WALAM-Waltheria americana. HYPSU-Hyptis suaveolens

The Triunfetta bartramia (TIUBA) presented intermediate values of RIs (10-22\%), which ranked this species as the third in terms of relative importance among weeds (Figure 1). 
The other species presented RIs below $10 \%$ regardless of the period during which the evaluation was performed (Figure 1). This does not disqualify such species as possible competitors for environmental resources.

\subsection{Forage Morphology and Structure}

All variables related to the morphology of $P$. maximum cv. Mombaça were influenced by the presence of weeds. Tiller height was lower than $125.0 \mathrm{~cm}$ in coexistence periods shorter than 30 DAE. However, periods of coexistence equal to or greater than 45 DAE promoted heights above $148.0 \mathrm{~cm}$, statistically higher than the heights obtained in the periods of 0 (zero), 15 and 30 DAE (Figure 2A).

The effects of the presence of weeds on tiller diameter were inversely of that observed for height. The increase in the coexistence period promoted decreases in the diameter values of tillers of Guinea grass. It is noteworthy that only 15 days of coexistence were sufficient to significantly reduce the diameter of the tiller when compared to 0 (zero) DAE (Figure 2B).

A

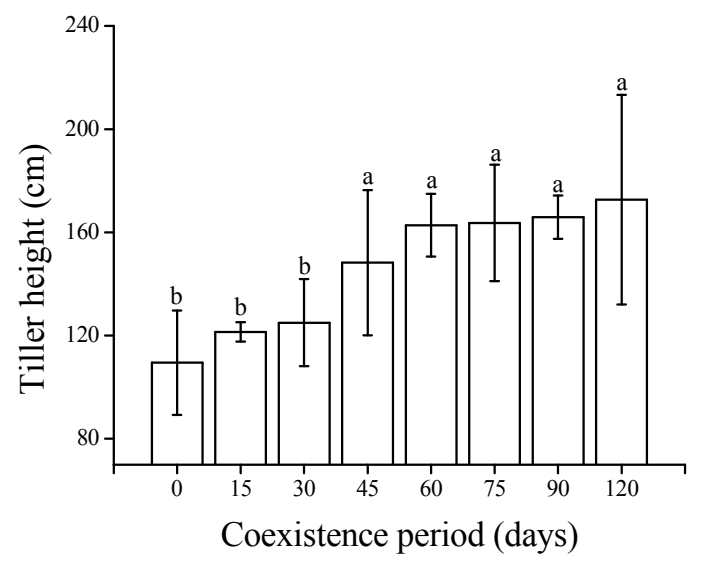

$\mathrm{C}$

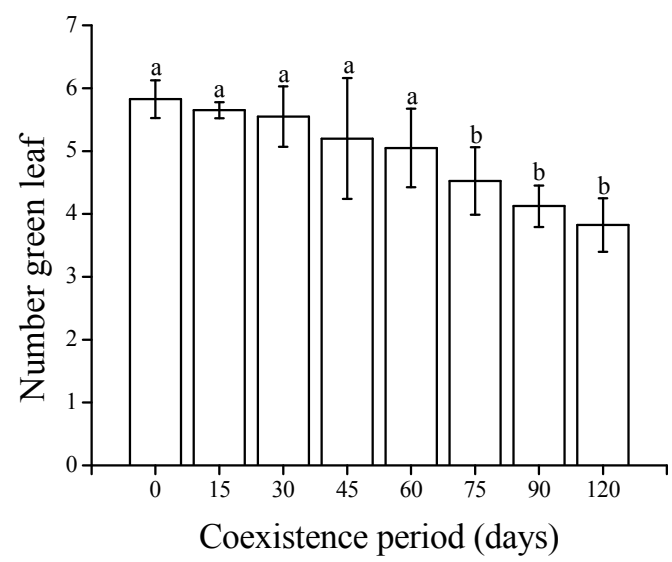

B

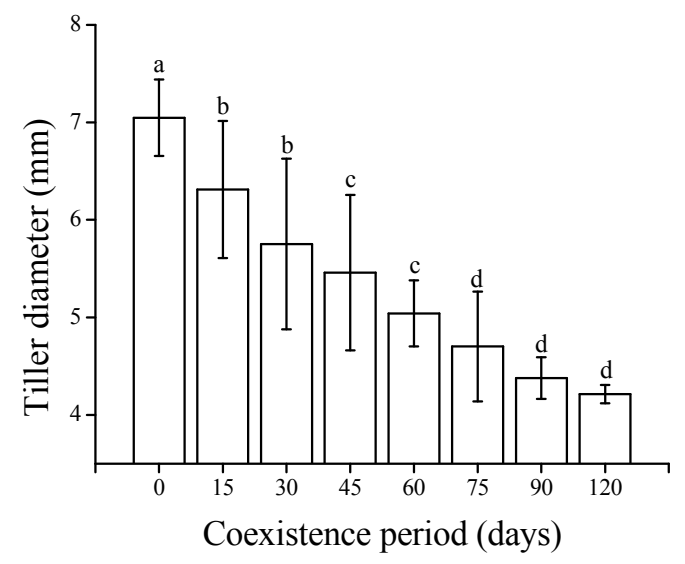

$\mathrm{D}$

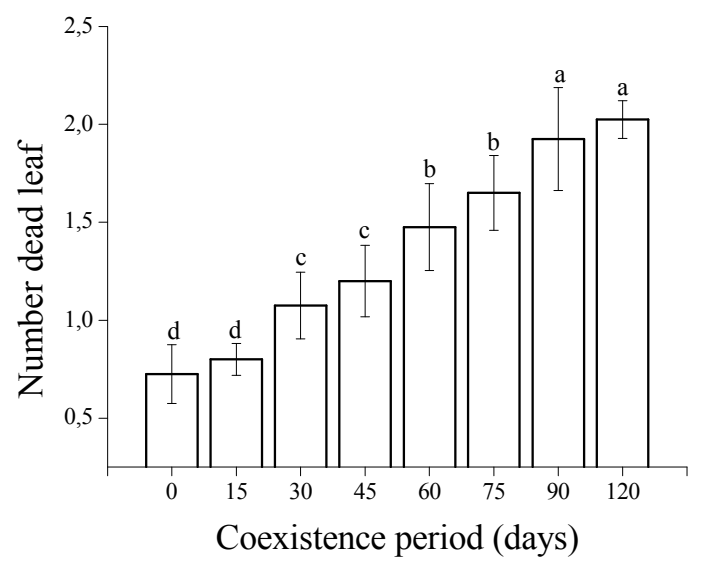

Figure 2. Tiller height (A), tiller diameter (B) and number of live leaves (C) and dead leaves (D) obtained in Guinea grass in function of coexistence periods with weeds

The increase in the period of coexistence with weeds also negatively influenced the number of green leaves produced by Guinea grass. The periods from 0 (zero) to 60 DAE produced on average 5.1-5.8 leaves per tiller. The averages produced by the periods 75,90 and 120 DAE were, respectively, 4.5, 4.1 and 3.8 leaves, which is statistically lower than the values obtained for the other periods of coexistence (Figure 2C).

The evaluation of dead leaves revealed the existence of four different levels of values. Statistically lower averages were obtained for the periods 0 (zero) and $15 \mathrm{DAE}$. The second level can be determined by the values obtained in the periods 30 and $45 \mathrm{DAE}$, followed by the values found in the periods 60 and $75 \mathrm{DAE}$. The highest and statistically higher values for dead leaves were caused by periods of 90 and 120 days of coexistence (Figure 2D).

Changes in the morphometry of Guinea grass can also be noted due to the relation between leaf biomass and stem biomass and the ratio between tiller height and height of the first green leaf. The increase in the coexistence period 
provided linear decreases in the leaf/culm ratio (Figure 3A) simultaneously with linear increases in the HT/HFGL ratio (Figure 3B).

A

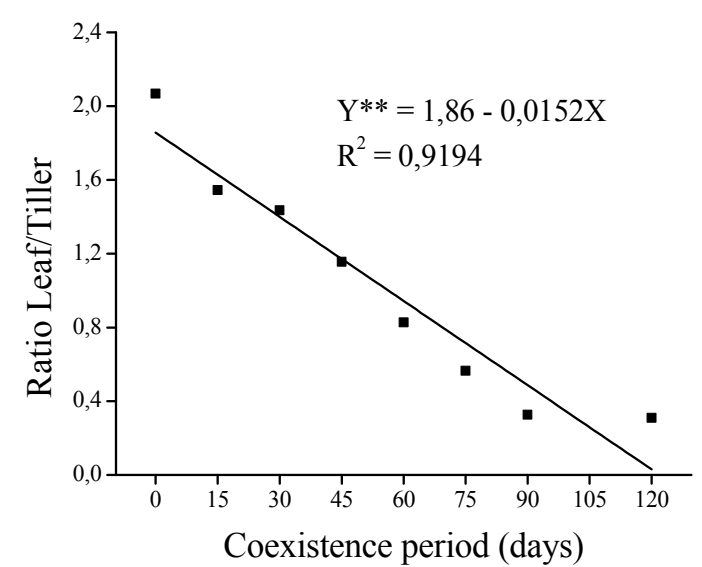

B

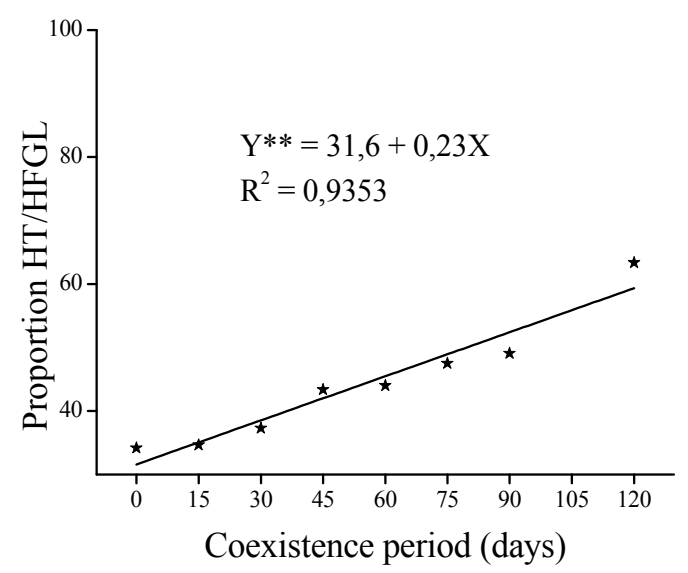

Figure 3. Relationship between dry biomass of leaf/culm (A) and proportion between tiller height and height of the first green leaf (B) obtained for Guinea grass in function of coexistence periods with weeds. ${ }^{* *} \mathrm{P}<0.01$

The morphostructural changes caused by the presence of weeds reflected on the productivity variables of Guinea grass. The VDGL obtained in the absence of coexistence with weeds (0 DAE) was $11.4 \mathrm{~g} \mathrm{~m}^{-3}$, statistically higher than the values obtained for coexistence periods equal to or greater than $15 \mathrm{DAE}$. It should be noted that the VDGL obtained at $15 \mathrm{DAE}$ was $7.6 \mathrm{~g} \mathrm{~m}^{-3}$ and, from this period on, the effect of weeds is even more negative, since it provided statistically lower values, below $4.5 \mathrm{~g} \mathrm{~m}^{-3}$ (Figure 4A).

Coexistence with weeds also affected stem production in Guinea grass. It is possible to see in Figure 4B that the VDGS was $7.6 \mathrm{~g} \mathrm{~m}^{-3}$ at 15 and $30 \mathrm{DAE}$, both statistically superior to the VDGS obtained for other periods of coexistence. There was a similarity between the VDGS values observed for the absolute control (0 DAE) and for the periods 45 and 60 DAE. However, the coexistence with weeds for periods equal to or greater than 75 DAE statistically provided the lowest values for VDGS (below $4.8 \mathrm{~g} \mathrm{~m}^{-3}$ ).

The volumetric density of dead material (VDDM) had a pattern of variation different from the other productivity variables evaluated. The lowest value of $\operatorname{VDDM}\left(0.9 \mathrm{~g} \mathrm{~m}^{-3}\right)$ was observed in the absence of coexistence with weeds (0 DAE); however, it was statistically similar to the 60, 90 and $120 \mathrm{DAE}$ (Figure 4C). The lowest production of dead material obtained at $0 \mathrm{DAE}$ is due to the non-competition within the population of Guinea grass (intraspecific), indicating that the seeds were used in a correct quantity during the experiment set up process. However, the lowest VDDM values obtained at 90 and 120 DAE are due to morphostructural changes imposed by the mutual coexistence with weeds, as previously mentioned.

A

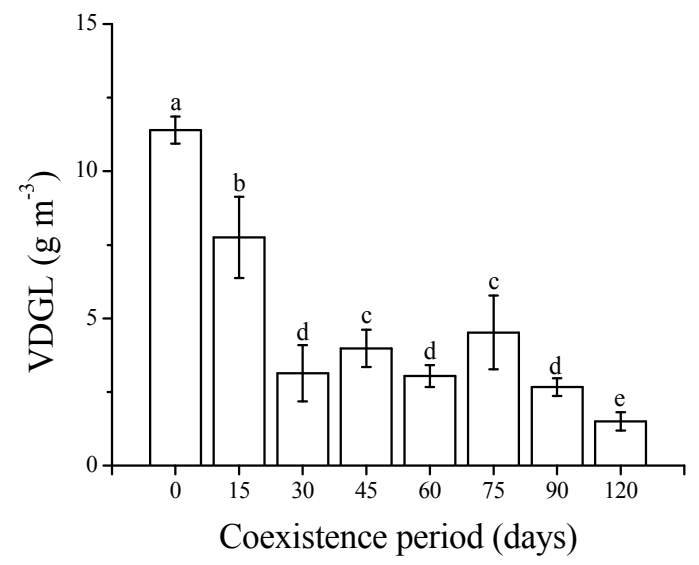

B

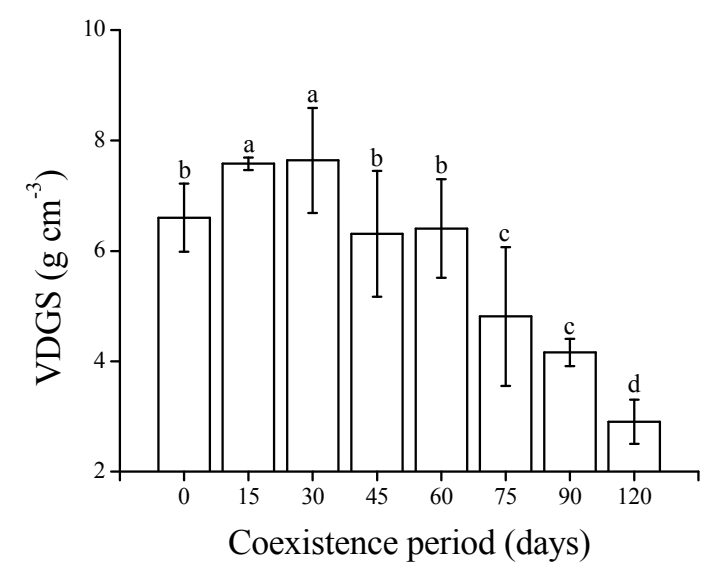



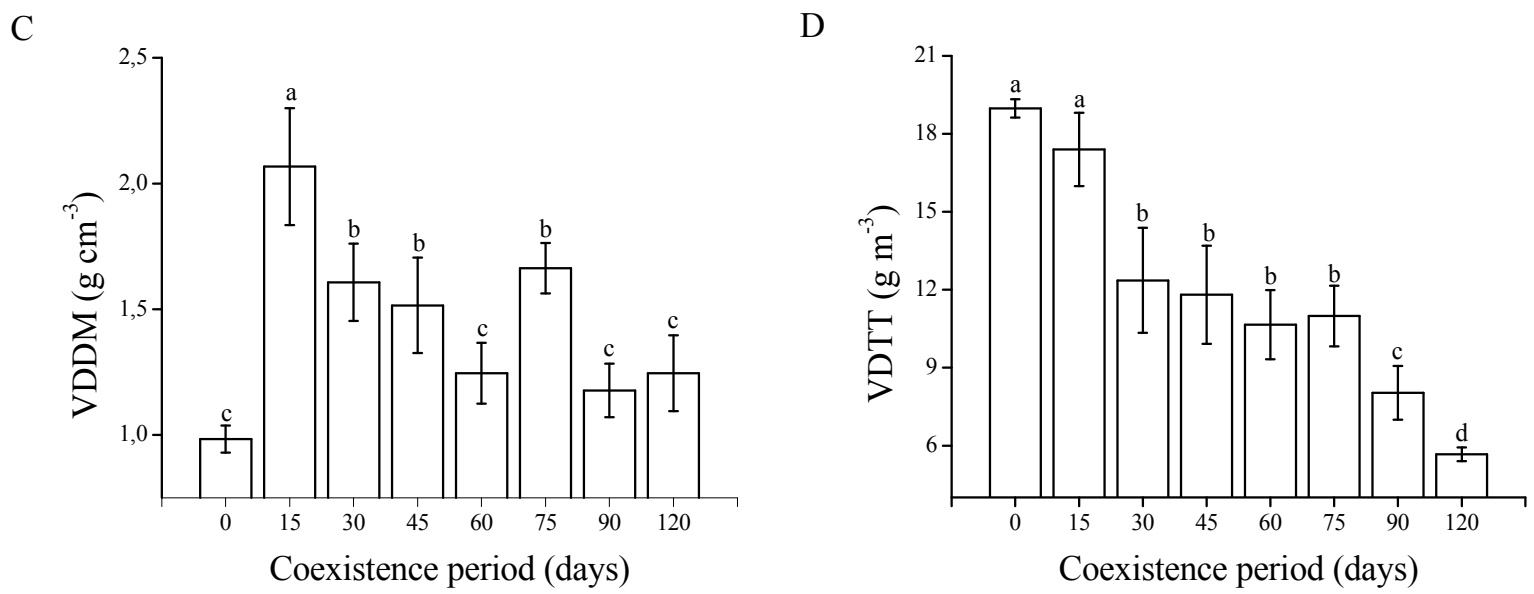

Figure 4. Volumetric density of green leaf-VDGL (A), green stem-VDGS (B), dead material-VDDM (C) and total-VDTT (D) obtained in Guinea grass according to the periods of coexistence with weeds

On the other hand, the highest amount of dead material $(\mathrm{P}<0.0001)$ found for the 15 DAE coexistence period is due to the high production of vegetative structures by Guinea grass (Figure $2 \mathrm{~B}$ and $\mathrm{C}$ ) associated to the change in the population density imposed by the presence of weeds and, consequently, the beginning of the biological relation of competition among the species.

By analyzing the total volumetric density, which represents the sum of the volumetric densities of all fractions, the increase in coexistence with weeds provided progressive decreases in VDTT values (Figure 4D). The reductions were more drastic $(\mathrm{P}<0.01)$ for periods equal to or higher than $30 \mathrm{DAE}$, and reached only $5.7 \mathrm{~g} \mathrm{~m}^{-3}$ when the coexistence period was 120 DAE, which represents a reduction of $70 \%$ in VDTT $\left(19.0 \mathrm{~g} \mathrm{~m}^{-3}\right)$ obtained in the absence of coexistence (Figure 4D).

\subsection{Forage NUTRITIONAL QUALIty}

Neutral detergent fiber (NDF) contents were not influenced by coexistence with weeds. All NDF values did not differ statically (P>0.05) and were above 60\% (Figure 5A). According to Van Soest (1994), within this range there would be a restriction of the consumption of bulk. The high NDF values (above 70\%) obtained in this study, including for the control, are probably related to the date on which the final evaluation of the forage was carried out, since NDF values naturally tend to be higher according to the plant's age.

A

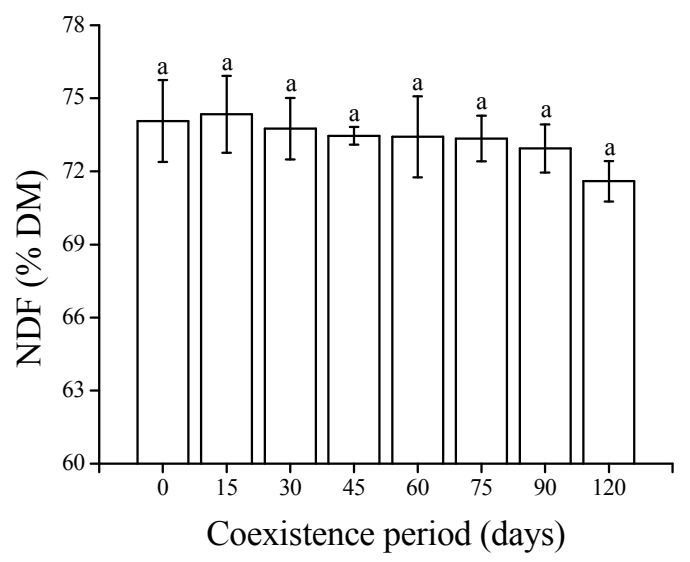

B

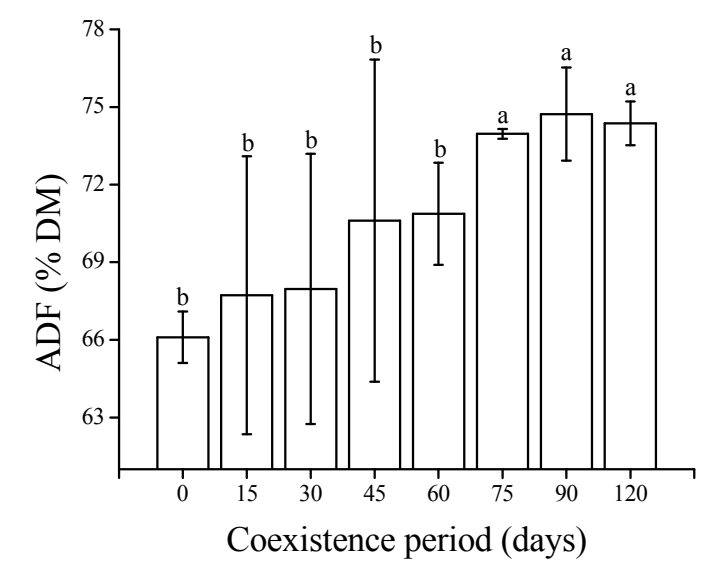




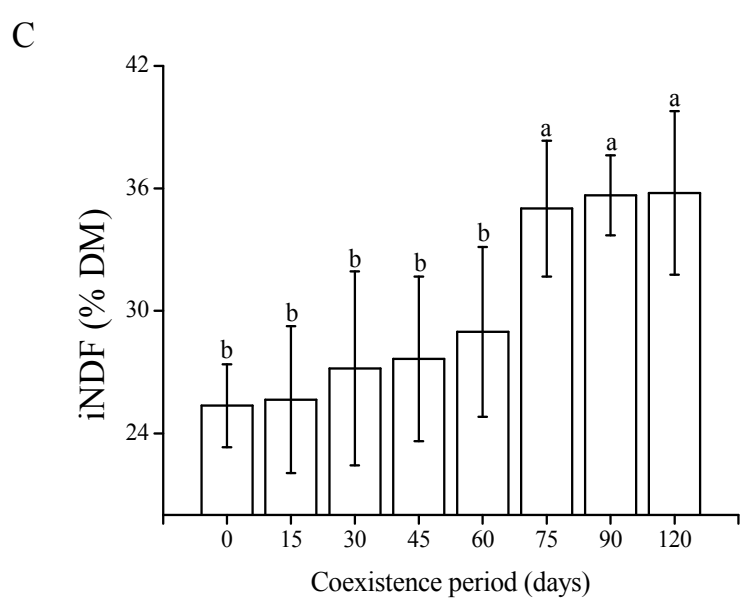

Figure 5. Levels of neutral detergent fiber-NDF (A), acid detergent fiber-ADF (B) and indigestible neutral detergent fiber-iNDF (C) obtained for Guinea grass in function of the periods of coexistence with weeds

The levels of ADF and iNDF increased as the period of coexistence with weeds increased, with a significant difference after 75 DAE (Figures 5B and 5C). On the other hand, IVDOM levels (Figure 5D) decreased markedly with the increase in the coexistence period, and only 15 days were enough to cause significant decreases in both variables when compared to the absence of coexistence (Figures 5D and 5E).

Crude protein (CP) levels also changed significantly due to weeds, and decreased as the coexistence period increased. Again, $15 \mathrm{DAE}$ of coexistence were enough to reduce $\mathrm{CP}$ levels $(\mathrm{P}<0.001)$, and the lowest values were obtained when the coexistence was equal to or greater than 45 DAE (Figure 6A). As expected, ADIN and N-ADF levels followed the same pattern as those obtained for ADF and iNDF. ADIN and N-ADF values were similar to the control $(\mathrm{P}>0.05)$ at 15, 30, 45 and $60 \mathrm{DAE}$ (Figures $6 \mathrm{~B}$ and $6 \mathrm{C}$ ).

A

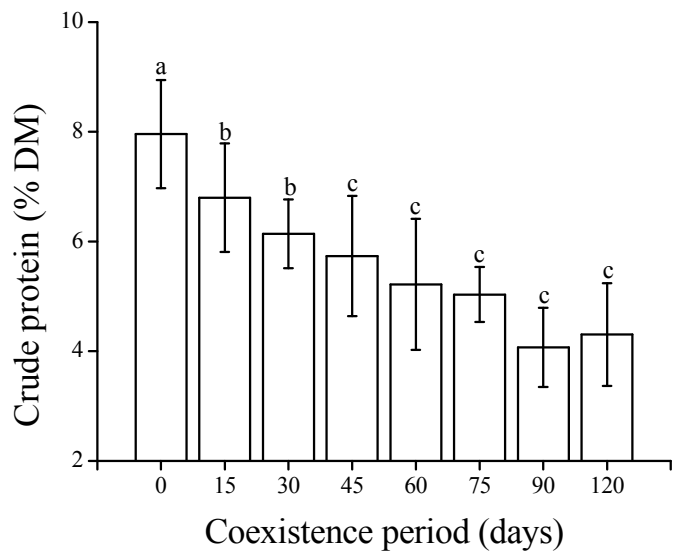

B

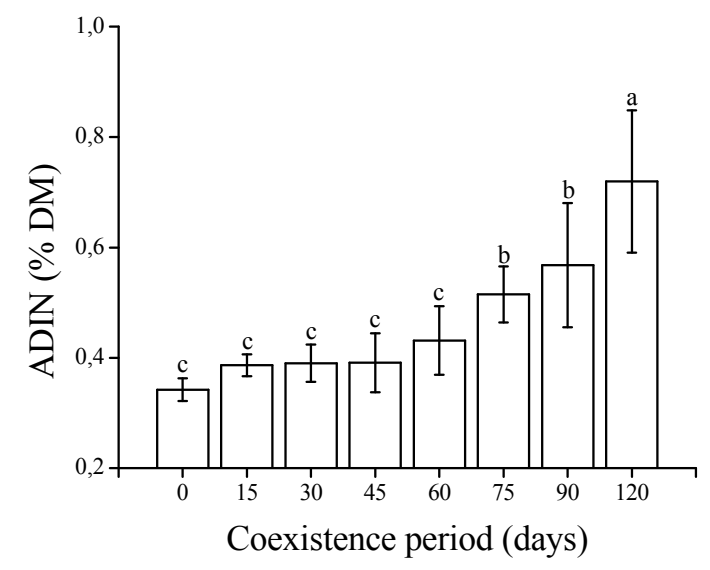




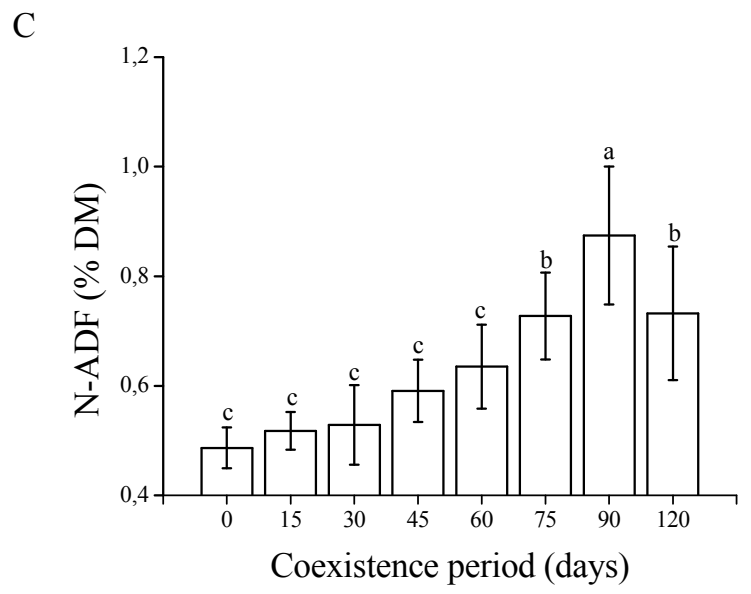

Figure 6. Contents of crude protein-CP (A), acid detergent insoluble nitrogen-ADIN (B) and acid detergent fiber-bound nitrogen-N-ADF (C) obtained for Guinea grass in function of the periods of coexistence with weeds

The in vitro digestibility of organic matter (IVDOM) decreased following quadratic proportions $(\mathrm{P}<0.01)$ as the coexistence period increased (Figure 7A). The total digestible nutrient (TDN) decreased linearly according to the period of coexistence with weeds (Figure 7B). The negative influence of weeds is also observed on digestible (DE) and metabolizable $(\mathrm{ME})$ energy of Guinea grass, since linear reductions $(\mathrm{P}<0.01)$ occurred with the progression of coexistence with weeds (Figures 7C and 7D). In fact, the influence of weeds on IVDOM and TDN was expected since there were negative influences on different fiber and $\mathrm{CP}$ fractions of Guinea grass. The reduction in DE and ME values is also logical considering that much of the food energy assessment is estimated from TDN.

\subsection{Potential Gas Production}

The evaluations of potential for gas production of Guinea grass revealed that the coexistence with weeds contributed to an increase of GHG emissions. The total gas production was higher when the coexistence period was 120 DAE $(\mathrm{P}<0.01)$. However, the total emission of gas decreased by approximately $6.5 \%$ when the period was $90 \mathrm{DAE}$ and about $20 \%$ in the periods $30,45,60$ and 75 DAE. The lowest $(\mathrm{P}<0.01)$ total gas emissions were obtained during periods 0 and 15 days of coexistence with the weed community (Figure 8A).

The emission potential of $\mathrm{NH}_{4}$ by Guinea grass followed practically the same pattern regarding the effects of coexistence with weeds. Emissions above $6.89 \mathrm{~mL} \mathrm{~g}^{-1}$ of OM were obtained for the periods 90 and $120 \mathrm{DAE}$, and below $5.58 \mathrm{~mL} \mathrm{~g}^{-1}$ of $\mathrm{OM}(\mathrm{P}<0.01)$ for 0 and $15 \mathrm{DAE}$ coexistence period. The coexistence of 30, 45, 60 and 75 DAE produced intermediate values of $\mathrm{NH}_{4}$ emission potential: between 6.28 and $6.38 \mathrm{~mL} \mathrm{~g}^{-1}$ of OM (Figure 7B).

The period of coexistence of $120 \mathrm{DAE}$ was also responsible for the highest emission value of $\mathrm{CO}_{2}$ by Guinea grass $(\mathrm{P}<0.01)$, representing the production of $50.6 \mathrm{~mL} \mathrm{~g}^{-1}$ of $\mathrm{OM}$. The 45,75 and $90 \mathrm{DAE}$ periods provided intermediate levels of emission: between 43.7 and $44.5 \mathrm{~mL} \mathrm{~g}^{-1}$ of OM. Values below $41.2 \mathrm{~mL} \mathrm{~g}^{-1}$ of OM (similar levels) $(\mathrm{P}>0.05)$ were obtained for the $0,15,30$ and $60 \mathrm{DAE}$ periods of coexistence with weeds (Figure $8 \mathrm{C}$ ).

A

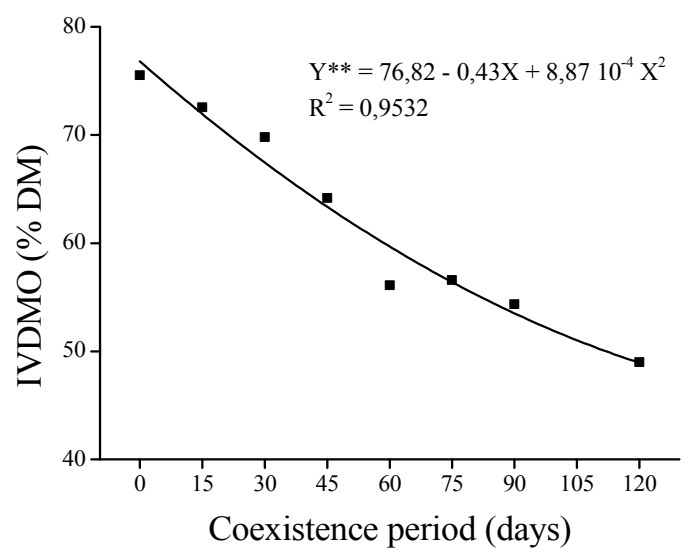

$\mathrm{D}$

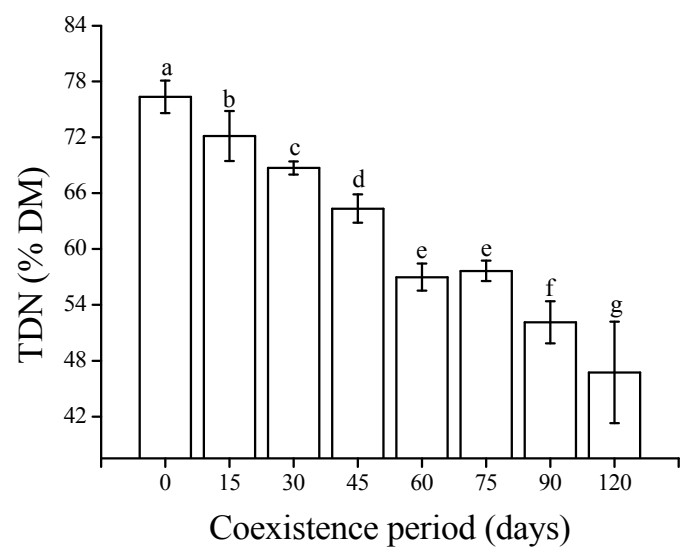


$\mathrm{C}$

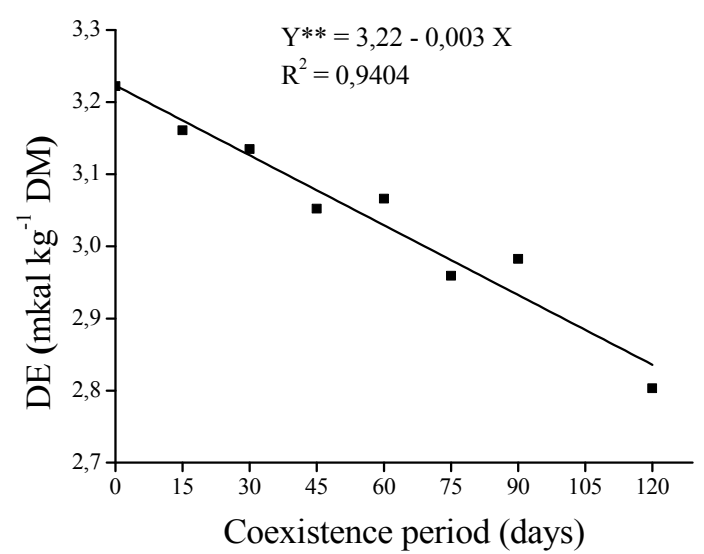

$\mathrm{D}$

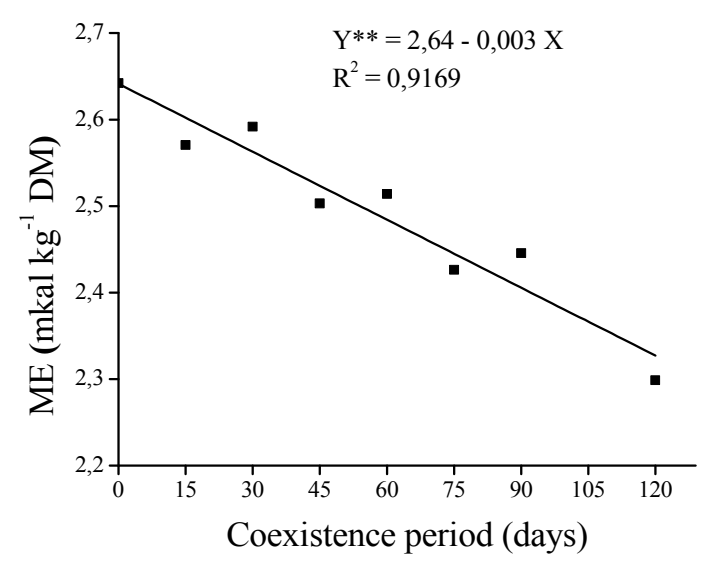

Figure 7. Contents of in vitro digestibility of organic matter-IVDOM (A), total digestible nutrient-TDN (B), digestible energy-DE (C) and metabolizable energy-ME (D) obtained for Guinea grass in function of periods of coexistence with weeds. ${ }^{* *} \mathrm{P}<0.01$

A

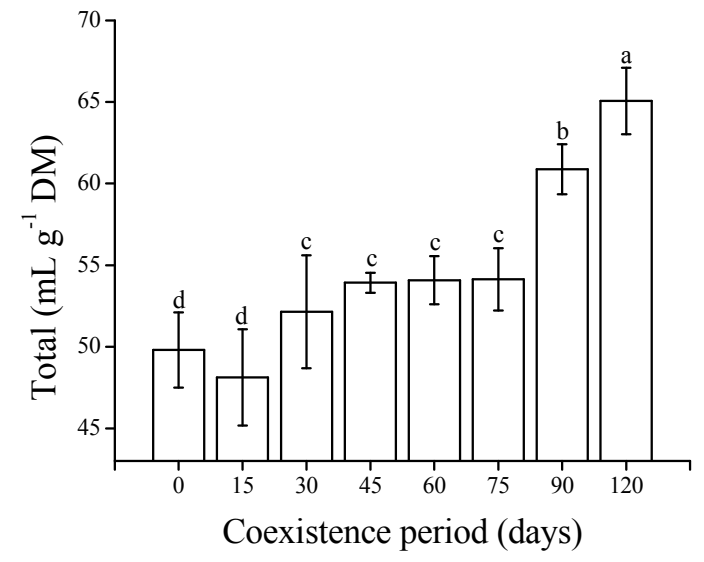

$\mathrm{C}$
B

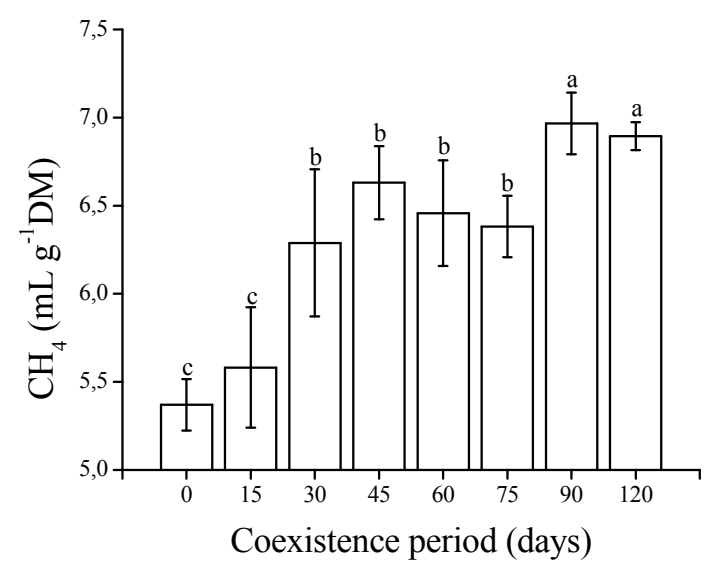

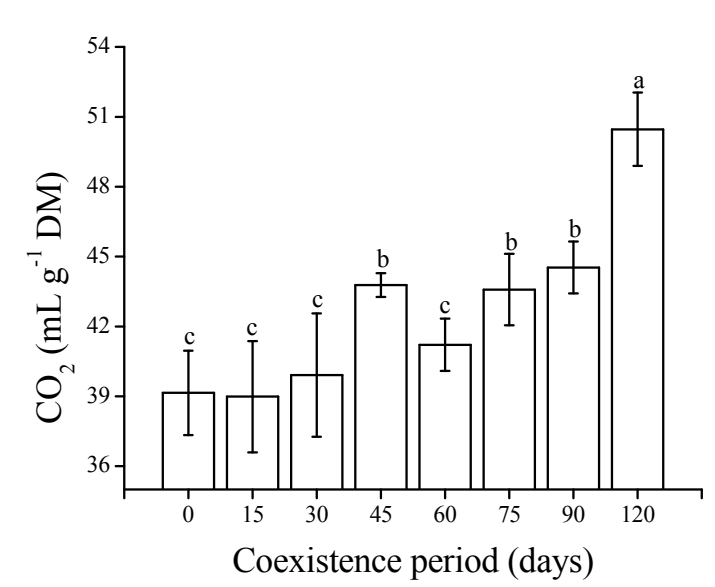

Figure 8. Total volume of gas (A), volume of methane- $\mathrm{CH}_{4}(\mathrm{~B})$ and volume of carbon dioxide- $\mathrm{CO}_{2}(\mathrm{C})$ produced by the dry matter of Guinea grass in function of the periods of coexistence with weeds

\section{Discussion}

Pasture degradation is a worldwide phenomenon and can be defined as an evolutionary process of loss of vigor, productivity and natural recovery capacity of forages. Typically, more than one cause is involved in the degradation process. There is a particular emphasis on the high intensity of forage grazing, absence of periodic soil fertility replacement and excessive use of fire to eliminate uncharged forage or to eliminate weeds. In addition, 
grazing failures caused by inadequate preparation, use of low quality seeds or sowing at inappropriate times also contribute to the beginning of the degradation process. Generally, the low productivity of livestock is associated with degradation, causing significant economic and environmental damage (Harris, 2010; Miehe et al., 2010; Dias-Filho, 2011; Reis, 2017).

The most rational solution for such areas where an extreme level of degradation is diagnosed is pasture renewal. It consists in the destruction of the old vegetation, correction of soil fertility and sowing of a forage species appropriate to local environmental conditions (Macedo, 2009).

However, all such activities are inefficient to eliminate the seed bank left by weeds, which will germinate together with forage seeds and rapidly initiate a new degradation process (Marchi et al., 2017).

The previous presence of weed seeds was confirmed in this study, since eleven different species occurred during the experimental period, especially CASOB, HYPSU and TIUBA in terms of importance (Table 1 and Figure 1). These results corroborate with a phytosociological study carried out by Marchi et al. (2017) in a pasture of Brachiaria brizantha cv 'Marandú'. The authors reported that $S$. obtusifolia and H. suaveolens were the species within the weed community that presented the highest indexes of importance values.

The main fact to be highlighted in this study in relation to the phytosociological evaluation is that there has always been the presence of at least one weed species throughout the experimental period (Figure 1). Even though the relative importance of each species has fluctuated (Figure 1), all eleven species together, that is, the weed community, were sufficient to establish a biological relationship of competition with Guinea grass, and thus potentially cause changes in forage grass morphogenesis from the first days after the emergence of seedlings.

Processes of formation and development, that is, leaf morphogenesis, are fundamental for plant growth, considering the importance of leaves in the process of photosynthesis, a starting point for the formation of new tissues (Santos et al., 2012). Leaf morphogenesis in forage grasses during their vegetative growth is characterized by three factors: appearance rate, elongation rate and leaf longevity. The appearance rate and leaf longevity establish the number of live leaves per tiller. They are genetically determined and may be affected by environmental factors and management practices (Costa et al., 2017).

Tropical forages, once shaded, tend to increase stem elongation and leaf senescence in order to obtain sunlight and better survival conditions (Casagrande et al., 2010). This causes a strong accumulation of fibrous material, a decrease in the relation leaf/stem and, consequently, a lower food intake by animals (Lemaire et al., 2011).

Thus, the increase in height (Figure 2A) and the decrease in the diameter of tillers (Figure 2B), the low production of green leaves (Figure 2C), the increase in the number of dead leaves (Figure 2D), and the elevation of the live leaf position (Figure 3B) as found in this study characterize plant etiolation, a typical behavior of plants subjected to low luminosity (Marchi et al., 2017). Thus, the presence of weeds caused the shading of the forage grass and a biological relationship of competition for the light factor, established as early as the first two weeks of coexistence with weeds. This significantly changed the leaf morphogenesis of Guinea grass.

In contrast, the change in leaf morphogenesis may compromise the structure of the forage canopy, which is understood as the spatial arrangement of the organs in shoots of plants and which has a marked effect on the grazing habit of animals (Mezzalira et al., 2014). The live leaf is the morphological component that composes most of the diet preferred by animals because of its greater digestibility, accessibility and its lower resistance (Oliveira et al., 2016). In addition, the green stem and dead material may negatively affect the ingestive behavior by hindering the animal's forage harvest during grazing (Santos et al., 2011). Mezzalira et al. (2014) reported that pastures containing a higher proportion of stems, or where live leaves are sparser and scarce, reflect the increased time for bit formation, which may lead to an increased energy expenditure by animals during feeding.

The results for volumetric density obtained in this study indicate that the presence of weeds, besides competitively reducing the amount of food produced (Figure 4D), also changed the pasture structure due to a differential use of photoassimilates by Guinea grass (Figures 4A, 4B and 4C). Consequently, it changes the form by which the forage is available to the animal. This change in forage canopy may reduce the effectiveness of the animal grazing habit and, consequently, the profitability of the livestock activity.

According to Oliveira et al. (2016), the forage canopy structure, besides influencing the ingestive behavior, is also a preponderant factor in determining the quality of the feed offered to animals, especially due to its influence on the fibrous fractions more difficult to digest.

The NDF is a dietary factor quite representative of the volume occupied by the food. Diets with a high proportion of fiber fill the spaces of the rumen-reticulum, directly influencing the consumption and digestibility of animals. In diets with a low NDF (high energy), by increasing digestibility the consumption would be limited by energy 
satiation. In diets with a high NDF (low energy), where the filling would be promoting intake limitation, the digestibility would reduce this effect, increasing both the passage rate and feed intake (Lima et al., 2015; Sampaio et al., 2016).

The levels of ADF and iNDF can be used as indicators of diet digestibility. The higher these values, the worse the food quality and the longer the retention time in the rumen of the animal, thus affecting the passage rate. Difante et al. (2009) stated that ADF values around $30 \%$ or lower provide a higher intake, while forages with levels above $40 \%$ represent lower intakes. The high content of ADF also indicates a higher proportion of the most resistant fiber constituents, such as resistant pentosans, cellulose, lignin and cutin, which are components of the cell wall responsible for the low digestibility of forages (Van Soest, 1994). The lower the ADF (Figure 5B), the higher the energy value of the plant (Figures 7C and 7D), the lower the lignin content and consequently the better the digestibility of the food (Figure 7A).

Similarly, the increase in iNDF contents (Figure 5C) reflects on the reduction of forage quality, since this component negatively affects animal consumption. The NDF, together with the ADF and iNDF, are determinants in the repletion process, that is, the food's ability to promote physical filling in the rumen, which directly affects voluntary consumption (Costa et al., 2011, Pesqueira-Silva et al., 2015).

The change in the structure of the forage canopy also produced changes in the nitrogen fractions that compose the dry matter of Guinea grass (Figure 6). The ADIN is the unavailable nitrogen and, by being insoluble in acid detergent, is composed of proteins and nitrogen compounds associated with lignin, tannins and Maillard products, which are highly resistant to microbial attacks and ruminal degradation (NRC, 2001). In the Maillard reaction, the protein reacts with the carbohydrates of the plant and becomes part of the ADF fraction (Van Soest, 1994). However, Brennecke et al. (2011) suggest that the ADIN is not totally indigestible, presenting a digestibility of about $30 \%$ for forages. The nitrogen retained as N-ADF is practically indigestible and generally associated with lignin and other compounds of difficult degradation (Oliveira et al., 2010). In addition, increases in N-ADF levels may occur when there is an excessive heat production and according to the physiological age of the plant. This may compromise the integrity and availability of the nitrogen fraction and, consequently, result in slower rates of degradation in the digestive tract of the animal (Sniffen et al., 1992; Possenti et al., 2016).

However, Marchi et al. (2017) stated that the canopy structure can also change due to the action that weeds exert on the competition for environmental resources. Mineral nutrients are one of the most contentious factors among competing individuals. Even though soil fertility has been corrected in the area where the experiment was installed, weeds were able to recruit chemical components (especially nitrogen) when compared to the forages. The higher production of stem fibers in relation to green leaf production (Figure 3A) associated with the competition for the available nitrogen in the soil is the reason why there was a low conversion of the nitrogen absorbed by Guinea grass into nitrogen compounds of easy degradation (Figure 6A) concomitantly with the higher conversion into nitrogen compounds of difficult degradation (Figures 6B and 6C).

The changes that occurred in the chemical composition, especially the decrease in CP contents (Figure 6A) and the increase in the fiber fractions (Figure5B and 5C), directly affected the IVDOM contents of Guinea grass (Figure 7A). In turn, digestibility represents how much of the forage consumed will be effectively digested in the gastrointestinal tract of the animal for later absorption and use of compounds in metabolic routes (NRC, 2001). In addition, digestibility also influences the feed passage rate through the gastrointestinal tract and may compromise the animal's productive performance by $10-40 \%$. As a rule, plant tissues with a low digestion correlate negatively with $\mathrm{CP}$ and positively with fiber and lignin contents, and require a longer rumen retention time for fibrolytic processes to occur (Oliveira et al., 2016).

The concentration of potentially digestible components, comprising soluble carbohydrates, protein, minerals and other cellular contents, tend to decrease as the plants ripe. At the same time, the proportion of lignin, cellulose, hemicellulose and other indigestible fractions, such as cuticle and silica, increases. Consequently, there are decreases in digestibility (NRC, 2001).

In this study, it is evident that the presence of weeds promoted a change in structural and non-structural carbohydrate portions and probably increased the proportion of lignin, cellulose, hemicellulose and other indigestible fractions (Figure 5) related to the cells of Guinea grass.

The contents of total digestible nutrient (TDN) better represent the nutritional quality of the food. As the TDN values increase, more nutrients will be available and consequently there will be a higher digestible energy (DE) available for animal yield (Morais et al., 2016). Tropical forage grasses can be considered of a low nutritional quality when they have a TDN of less than $60 \%$ (Valadares Filho et al., 2016), a value obtained when the coexistence with weeds was equal to or greater than 60 DAE (Figure 7B). 
However, for the feeding of animals with high energy requirements, the productivity indexes alone lose focus, and the nutritive value of forage plants becomes prominent, since this qualitative aspect interferes directly with the digestion process, affecting animal performance (Pereira, 2013). Most nutrients in food, mainly energy and protein sources, are transformed into short chain fatty acids (SCFA), microbial mass and gases such as $\mathrm{CH}_{4}, \mathrm{CO}_{2}$, nitrous oxide $\left(\mathrm{N}_{2} \mathrm{O}\right)$ and hydrogen $\left(\mathrm{H}_{2}\right)$ (Baker, 1999; Chaves et al., 2006).

In general, the gas production tends to increase when the nutritional quality and the digestibility of the food ingested are low. There is a great collaboration of the fiber fraction of the food for the production of total gases (Morgado et al., 2012). This is because more fibrous foods remain in the rumen for longer and stimulate the development of microbial biomass with cellulolytic and methanogenic activity. The longer the time the particles remain in the interior of the rumen, the greater the amount of $\mathrm{NH}_{4}$ produced per unit of forage digested (Archimède et al., 2011). In addition, the production of $\mathrm{CO}_{2}$ and $\mathrm{NH}_{4}$ represents losses of $2-12 \%$ of the energy ingested, besides contributing to global warming (Aluwong et al., 2011).

This was confirmed in this study. The values for total gas volume (Figure 8A), methane volume (Figure 8B) and carbon dioxide volume (Figure $8 \mathrm{C}$ ) increased relatively as nutritional quality decreased (Figures 7A and 7B), causing considerable losses in the energy values of food (Figures 7C and 7D).

In addition, it is important to note that $\mathrm{CH}_{4}$ is 23 times more potent for global warming than $\mathrm{CO}_{2}$, and $87 \%$ of the total $\mathrm{CH}_{4}$ are produced in the rumen and $13 \%$ in the large intestine of the ruminant (Aghsaghali \& Naser, 2011).

\section{Conclusions}

By associating the results obtained for plant morphogenesis, nutritional quality and energetic value of the food and GHG production potential, we conclude that areas with unproductive and degraded tropical pastures that underwent a renewal process are subject to weed interference few weeks after the emergence of seedlings. Weed interference directly affects the initial development of plants by modifying the morphogenesis of Guinea grass, especially with regard to the formation of structural units rather than the production of leaves. This change in the structure of the forage canopy determines a lower nutritional value, loss in the energy value of the food for the maintenance of animals, and a greater GHG production potential. Thus, even if renewal practices were adopted, such as the use of suitable forage species for the production site, good quality seeds and the correct amount of sowing and correction of soil fertility, it is possible that in only 120 days, the pasture returns to a situation similar to the previous degradation condition, that is, low productive indexes associated with a high GHG emission potential.

In addition, the results obtained also suggest that a greater profitability and mitigation of GHG emissions can be achieved if weed control measures are adopted up to 30 days after emergence of seedlings in pasture renewal areas. This guarantees economic and environmental sustainability to the production of ruminants in tropical regions.

\section{References}

Aghsaghali, A. M., \& Naser, M. S. (2011). Factors affecting mitigation of methane emission from ruminants I: Feedings strategies. Asian Journal of Animal and Veterinary Advances, 6, 888-908. https://doi.org/ 10.3923/ajava.2011.888.908

Aluwong, T., Wuyep, P. A., \& Allam, L. (2011). Livestock-environment interactions: Methane emissions from ruminants. African Journal of Biotechnology, 10, 1265-1269.

Antoniel, L. S., Prado, G., Rocha, T., Bombardelli, W. W. A., Beltrame, G. A., \& Bueno, J. I. (2016). Irrigation on crude protein content of two pasture species. Irriga, 1(Special Edition), 248-259. https://doi.org/ 10.15809/irriga.2016v1n1p248-259

Archimède, H., Eugène, M., Marie Magdeleine, C., Boval, M., Martin, C., Morgavi, D. P., ... Doreau, M. (2011). Comparison of methane production between $\mathrm{C} 3$ and $\mathrm{C} 4$ grasses and legumes. Animal Feed Science and Technology, 166-167, 59-64. https://doi.org/10.1016/j.anifeedsci.2011.04.003

Baker, S. K. (1999) Rumen methanogens, and inhibition of methanogenesis. Australian Journal of Agricultural Research, 50, 1293-1298. https://doi.org/10.1071/AR99005

Barbosa, J. C., \& Maldonado Jr., W. (2015). Experimentação agronômica \& AgroEstat (p. 396). Sistemas Para Análises Estatísticas e Ensaios Agronômicos, Gráfica Multipress Ltda, Jaboticabal.

Bellé, J. R., Marchi, S. R., Martins, D., Sousa, A. C., \& Pinheiro, G. H. R. (2018). Nutritional value of Marandú palisade grass according to increasing coexistence periods with weeds. Planta Daninha, 36, 1-11. https://doi.org/10.1590/s0100-83582018360100070 
Brennecke, K., Tech, A. R. B., Arce, A. I. C., Luz, P. H. C., Herling, V. R., \& Costa, E. J. X. (2011). Prediction of protein fractioning of Brachiaria brizantha cv Marandu through Artificial Neural Networks. Archivos de Zootecnia, 60, 1271-1279. https://doi.org/10.21071/az.v60i232.4011

Carvalho. R. M., Pimentel, R. M., Fonseca, D. M., \& Santos, M. E. R. (2016). Effects of weed plants on tiller characteristics in Brachiaria pasture. Boletim da Indústria Animal, 73, 103-110. https://doi.org/10.17523/ bia.v73n2p103

Casagrande, D. R., Ruggieri, A. C., Janusckiewicz, E. R., Gomide, J. A., Reis, R. A., \& Valente, A. L. S. (2010). Morphogenetic and structural traits of Marandugrass pasture under continuous grazing with different forage supply. Revista Brasileira de Zootecnia, 39, 2108-2115. https://doi.org/10.1590/S1516-35982010001 000002

Chaves, A. V., Thompson, L. C., Iwaasa, A. D., Scott, S. L., Olsonm, M. E., Benchaar, C., \& McAllister, T. A. (2006). Effect of pasture type (Alfafa vs. Grass) on methane and carbon dioxide production by yearling beef heifers. Canadian Journal of Animal Science, 86, 409-418. https://doi.org/10.4141/A05-081

Costa, V. A. C., Detmann, E., Valadares Filho, S. C., Paulino, M. F., Carvalho, I. P. C., \& Monteiro, L. P. (2011). Intake and digestibility in cattle under grazing during rainy season and supplemented with different sources of nitrogenous compounds and carbohydrates. Revista Brasileira de Zootecnia, 40, 1788-1798. https://doi.org/10.1590/S1516-35982011000800024

Costa, N. L., Jank, L., Magalhães, J. A., Rodrigues, A. N. A., Fogaça, F. H. S, Bendahan, A. B., \& Santos, F. J. S. (2017). Forage yield, chemical composition and morphogenesis of Megathyrsus maximus cv. Mombaça under rest periods. PUBVET, 11, 1169-1174. https://doi.org/10.22256/pubvet.v11n11.1169-1174

De Zen, S., Barioni, L. G., Bonato, D. B. B., Almeida, M. H. S. P., \& Rittl, T. F. (2008). Pecuária de corte brasileira: Impactos ambientais e emissões de gases de efeito estufa.

Dias-Filho, M. B. (2011). Challenges of animal production in pastures in the Brazilian agricultural frontier. Revista Brasileira de Zootecnia, 40, 243-252.

Difante, G. S., Euclides, V. P. B., Nascimento Júnior, D., Silva, S. C., Torres Júnior, R. A. A., \& Sarmento, D. A. L. (2009). Ingestive behaviour, herbage intake and grazing efficiency of beef cattle steers on Tanzania guineagrass subjected to rotational stocking managements. Revista Brasileira de Zootecnia, 38, 1001-1008. https://doi.org/10.1590/S1516-35982009000100002

Euclides, V. P. B., Macedo, M. C. M., Zimmer, A. H., Jank, L., \& Oliveira, M. P. (2008). Evaluation of Panicum maximum cvs Mombaça and Massai under grazing. Revista Brasileira de Zootecnia, 37, 18-26. https://doi.org/10.1590/S1516-35982008000100003

Gléria, A. A., Silva, R. M., Santos, A. P. P., Santos, K. J. G., \& Paim, T. G. (2017). Beef cattle production in crop-livestock systems. Archivos de Zootecnia, 66, 141-150. https://doi.org/10.21071/az.v66i253.2138

Harris, R. B. (2010). Rangeland degradation on the Qinghai-Tibetan plateau: A review of the evidence of its magnitude and causes. Journal of Arid Environments, 74, 1-12. https://doi.org/10.1016/j.jaridenv.2009. 06.014

Jank, L., Martuscello, J. A., Euclides, V. P. B., Valle, C. B., \& Resende, R. M. S. (2013). Panicum maximum. In D. M. Fonseca, \& J. A. Martuscello (Eds.), Plantas Forrageiras (2nd ed., pp. 166-196). Editora UFV, Viçosa.

Kumar, S., Puniya, A. K., Puniya, M., Dagar, S. S., Sirohi, S. K., Singh, K., \& Griffith, G. W. (2009). Factors affecting rumen methanogens and methane mitigation strategies. World Journal of Microbiology and Biotechnology, 25, 1557-1566. https://doi.org/10.1007/s11274-009-0041-3

Lemaire, G., Hodgson, J., \& Chabbi, A. (2011). Grassland productivity and ecosystem services (p. 287). Cabi, Wallingford. https://doi.org/10.1079/9781845938093.0000

Licitra, G., Hernandez, T. M., \& Van Soest, P. J. (1996). Standardization of procedures for nitrogen fractionation of ruminants feeds. Animal Feed Science and Technology, 57, 347-358. https://doi.org/10.1016/ 0377-8401(95)00837-3

Lima, R. S., Gomes, J. A. F., Silva, E. G. S., Miranda, T. L., Aquino, R. S., \& Silva, A. F. (2015). Nutritional parameters in beef cattle: A review of intake, digestibility and feed conversion. PUBVET, 9, 135-142. https://doi.org/10.22256/pubvet.v9n3.135-142 
Macedo, M. C. M. (2009). Crop and livestock integration: The state of the art and the near future. Revista Brasileira de Zootecnia, 38, 133-146. https://doi.org/10.1590/S1516-35982009001300015

Magalhães, M. A., Martuscello, J. A., Fonseca, D. M., Oliveira, I. M., Freitas, F. P., Faria, D. J. G., ... Ribeiro Júnior, J. I. (2011). Morphogenesis and structural characteristics and production of guinea grass irrigated under different plants density and nitrogen doses. Revista Brasileira de Zootecnia, 40, 2308-2317. https://doi.org/10.1590/S1516-35982011001100005

Marcelino, K. R. A., Nascimento Junior, D., Silva, S. C., Euclides, V. P. B., \& Fonseca, D. M. (2006). Morphogenetic and structural traits and herbage production of marandugrass under intensities and frequencies of defoliation. Revista Brasileira de Zootecnia, 35, 2243-2252. https://doi.org/10.1590/ S1516-35982006000800007

Marchi, S. R., Bellé, J. R., Foz, C. H., Ferri, J., \& Martins, D. (2017). Weeds alter the establishment of Brachiaria brizantha cv. Marandu. Tropical Grasslands, 5, 85-93. https://doi.org/10.17138/TGFT(5)85-93

Marchi, S. R., Silva, H. M., Ferreira, C. F., Marques, R. F., \& Moraes, J. B. (2019). Interference of noxious shrubs on grazing behavior by bovines. Planta Daninha, 37(1), 1-10. https://doi.org/10.1590/s010083582019370100009

Mezzalira, J. C., Carvalho, P. C. F., Fonseca, L., Bremm, C., Cangiano, C., Gonda, H. L., \& Laca, E. A. (2014). Behavioural mechanisms of intake rate by heifers grazing swards of contrasting structures. Applied Animal Behaviour Science, 153, 1-9. https://doi.org/10.1016/j.applanim.2013.12.014

Miehe, S., Kluge, J., Von Wehrden, H., \& Retzer, V. (2010). Long-term degradation of Sahelian rangeland detected by 27 years of field study in Senegal. Journal of Applied Ecology, 47, 692-700. https://doi.org/ 10.1111/j.1365-2664.2010.01815.x

Morais, L. F., Nepomuceno, D. D., \& Almeida, J. C. C. (2016). Low nutritive value forage treatments for ruminants-a review. Acta Tecnológica, 11, 67-81.

Monquero, P. A., Hirata, A. C., \& Pitelli, R. A. (2014). Métodos de levantamento da colonização de plantas daninhas. In P. A. Monquero (Org.), Aspectos da biologia e manejo das plantas daninhas (pp. 103-127). Editora RiMa, São Carlos.

Morgado, E. S., Ezequiel, J. M. B., Galzerano, L., \& Homem Júnior, A. C. (2012). In vitro production of $\mathrm{CH}_{4}$ and $\mathrm{CO}_{2}$ in ruminal fluid of sheep fed diets containing high starch or neutral detergent fiber soluble associated or not with sunflower oil. Revista Cientifica de Produção Animal, 14, 81-84. https://doi.org/ 10.15528/2176-4158/rcpa.v14n1p81-84

NRC. (2001) Nutrient requirements of dairy cattle (7th ed., p. 381). National Academy of Sciences: Washington, DC.

Oliveira, L. B., Pires, A. J. V., Carvalho, G. G. P., Ribeiro, L. S. O., Almeida, V. V., \& Peixoto, C. A. M. (2010). Losses and nutritional value of corn, Sudan sorghum, forage sorghum and sunflower silages. Revista Brasileira de Zootecnia, 39, 61-67. https://doi.org/10.1590/S1516-35982010000100008

Oliveira, A. P., Casagrande, D. R., Bertipaglia, L. M. A., Barbero, R. P., Berchielli, T. T., Rugieri, C. C., \& Reis, R. A. (2016). Supplementation for beef cattle on Marandu grass pastures with different herbage allowances. Animal Production Science, 56, 123-129. https://doi.org/10.1071/AN14636

Paschoaloto, J. R., Ezequiel, J. M. B., Almeida, M. T. C., Fávaro, M. R., Homem Júnior, A. C., Carvalho, V. B., \& Perez, H. L. (2016). Inclusion of crude glycerin with different roughages changes ruminal parameters and in vitro gas production from beef cattle. Ciência Rural, 46, 889-894. https://doi.org/10.1590/ 0103-8478cr20151088

Pereira, L. G. R. (2013). Evaluation methods and enteric methane mitigation strategies in ruminants. Revista Colombiana de Ciencias Pecuarias, 26, 264-277.

Possenti, R. A., Arantes, A. M., Brás, P., Andrade, J. B., \& Ferrari Júnior, E. (2016). Nutritional evaluation of safflower silage and biomass, seed and oil production. Boletim da Indústria Animal, 73, 2326-243. https://doi.org/10.17523/bia.v73n3p236

Pesqueira-Silva, L. C. R., Zervoudakis, J. T., Araújo, C. V., Cabral, L. S., Hatamoto-Zervoudakis, L. K., Oliveira, A. A., \& Silva-Marques, R. P. (2015). Nutritional parameters of Nellore heifers grazing in grass marandu receiving energy, protein and multiple supplement the dry-rainy transition period. Semina: Ciências Agrárias, 36, 3293-3302. https://doi.org/10.5433/1679-0359.2015v36n5p3293 
Reis, E. (2017). Opportunities and challenges to the sustainable development of cattle raising in Brazil, 1970-2005. Economia, 18, 18-39. https://doi.org/10.1016/j.econ.2016.07.004

Sampaio, A. F., Mendes, F. B. L., Santana Júnior, H. A., Santana, E. O. C., Silva, R. R., \& Silva, F. F. (2016). Correlation between ingestive behavior and nutrient intake in grazing cows. Revista Científica de Produção Animal, 18, 110-120.

Santos, M. E. R., Fonseca, D. M., Gomes, V. M., Pimentel, R. M., Silva, G. P., \& Albino, R. L. (2011). Structure of signalgrass in relation to weeds. Acta Scientiarum-Animal Sciences, 33, 233-239. https://doi.org/ 10.4025/actascianimsci.v33i3.10439

Santos, M. R., Fonseca, D. M., Gomes, V. M., Silva, S. P., Silva, G. P., \& Reis, M. (2012). Correlations between structural and morphogenetic characteristics on signalgrass pastures. Ciência Animal Brasileira, 13, 49-56.

Seker, E. (2002). The determination of the energy values of some ruminant feeds by using digestibility trial and gas test. Revued Médicine Véterinaire, 153, 323-330.

Sejian, V., Lal, R., Lakritz, J., \& Ezeji, T. (2011). Measurement and prediction of enteric methane emission. International Journal Biometeorology, 55, 1-16. https://doi.org/10.1007/s00484-010-0356-7

Silva, D. J., \& Queiroz, A. C. (2002). Análise de alimentos (métodos químicos e biológicos) (3rd ed., p. 235). Viçosa, MG: Universidade Federal de Viçosa.

Sniffen, C. J., O’Connor, J. D., Van Soest, P. J., Fox, D. G., \& Russell, J. B. (1992). A net carbohydrate and protein system for evaluating cattle diets: II. Carbohydrate and protein availability. Journal of Animal Science, 70, 3562-3577. https://doi.org/10.2527/1992.70113562x

Van Soest, P. J. (1994). Nutritional ecology of the ruminant (2nd ed., p. 476). Ithaca, NY: Cornell University Press.

Valadares Filho, S. C., Silva, L. F. C., Gionbelli, M. P., Rotta, P. P., Marcondes, M. I., Chizzotti, M. L., \& Prados, L. F. (2016). Exigências nutricionais de zebuinos puros e cruzados (3rd ed., p. 327). Viçosa (MG): UFV, DZO. https://doi.org/10.5935/978-85-8179-111-1.2016B001

Vilela, L., Soares, W. V, Sousa, D. M. G., \& Macedo, M. C. M. (2003). Calagem e adubação para pastagens. In D. M. G. Sousa, \& E. Lobato (Eds.), Cerrado: Correção do solo e adubação (pp. 367-384). Planaltina, DF: Embrapa Informação Tecnológica.

\section{Copyrights}

Copyright for this article is retained by the author(s), with first publication rights granted to the journal.

This is an open-access article distributed under the terms and conditions of the Creative Commons Attribution license (http://creativecommons.org/licenses/by/4.0/). 